\title{
Top Management Commitment to Total Quality Management as A Correlate of Customer Satisfaction in the Nigerian Banking Sector
}

\author{
Article by Oparinde David Olusanjo \\ Management, Texila American University \\ E-mail:doparinde@hotmail.com
}

\begin{abstract}
The need for a comprehensive understanding of the connection between total quality management and customer satisfaction cannot be overstressed. It is on this note that this study seeks to examine the kind of relationship that exists between Total Quality Management and other three variables, vis-à-vis top management commitment, employee involvement, and customer satisfaction. The descriptive survey design was adopted for this study and primary data was collected with the use of a self-structured questionnaire from one hundred and thirty-six (136) randomly selected respondents among the employees of Access Bank Plc. (27); First Bank Nigeria Limited (35); Guarantee Trust Bank Plc. (30); United Bank for Africa (24); and WEMA Bank (20), in Akoka, Yaba Local Government Area of Lagos State, Nigeria. The hypotheses were tested using Pearson Product Moment Correlation Coefficient at 0.05 level of significance, with the aid of the Statistical Package for Social Scientists (SPSS 21.0). The findings of the study showed an increase in the Nigerian Banking Sector top management commitment to Total Quality Management will imply increase in TQM implementation; increase in the involvement of money deposit banks' staff in the TQM implementation process is also tantamount to an increase in the Total Quality Management implementation; and that implementation of Total Quality Management significantly correlates increase in customer satisfaction in the Nigerian banking sector. The study therefore recommends among others that the top management of the Nigerian banking sector should be committed to Total Quality Management and involve employees in its implementation.
\end{abstract}

Keywords: Top Management, Commitment, Total Quality Management, Employee Involvement, and Customer Satisfaction.

\section{Introduction}

\section{Background to the study}

There was an increase in the number of customer's complaints in the beginning from 1980s. The complaint is not limited to litigations in court rooms, board room and waiting rooms. Some of the business reacted by ignoring the voice of the customer while some customers established a customer relationship management to tract the net loyalty level of the customers. However, the customer satisfaction concept has now become a standard by which organization's performance are judged. Banking industry is the foundation for development in any nation. The economy of a nation is measured through the activities of production of goods and services of the citizen. The result of production of goods and services are geared towards improving the wealth of individual and society at large. The banking role in an economy is more of efficient allocation of resources, taking from the surplus side of the economy and taken to the deficit side of the economy. According to Odiaka (1991) Efficient and effective financial system is a prerequisite for the promotion of effective intermediation, competition, maintenance of confidence and stability of the economic system. It will also protect the bank against the risk of collapse. For the bank to have an efficient and effective system to perform their functions there is need for them to ensure total quality management philosophy in people, processes and products. The principles, practices and philosophies of Total Quality Management adopted (TQM) will determine how far the organization can go in delivering services that exceeds the needs and expectation of their customer. An organization is differentiated from their competitor 
based on the degree and level of commitment of the top management to total quality philosophy. Quality must be top priority in the people, top management, the product and services.

\section{Statement of problem}

From practical and theoretical perspectives, the need to comprehensively understand the correlation between customer satisfaction and total quality management cannot be over emphasized. Proper cooperation between employees, top and middle management towards a common objective requires a clear vision and mission, communicated by the top management. Hence top management commitment is crucial to ensure total quality management philosophy is enshrined as the part of company culture in order to exceeds the need and expectation of the customer.

Several researchers studied total quality management leaving some gaps that need to be filled behind. The study of the concept of total quality management has been a bone of contention that brings about tensions between regulatory, vernacular, contextual and conventional meanings. Previous studies on total quality management (e.g. Nadiri and Hussain 2005; Yang, 2006) were carried out in different situations and had diverse results, which give explanation for the need for the present study. The present business milieu requires that an organization maintains its business sustainability and produces products or services that constantly meet the yearnings of its customers and expectations (Muma et al., 2014). Total Quality Management (TQM) is one of the management strategies that can be adopted to achieve incessant improvement in quality. TQM as a concept came into being in 1970s when quality development took a tactical shift from Quality Control to quality strategic approach so as to heed to the increasing attention on quality. Quality management since then has developed gradually from Quality Inspection, to Quality Control, then to Quality Assurance and currently to Total Quality Management (Kenya Institute of Management, 2009).

\section{Objectives of the study}

The aim of the study is to evaluate top management commitment to total quality management as a correlate of customer satisfaction in the Nigerian banking sector. It is on this note that this study sets to achieve the following objectives

i) To examine the relationship between top management commitment and Total Quality Management implementation in the Nigerian Banking Sector;

ii) To find out if any correlation exists between employees' involvement and Total Quality Management implementation in the Nigerian Banking Sector;

iii) To determine the kind of relationship that exists between Total Quality Management implementation and Customer Satisfaction in the Nigerian Banking Sector

\section{Research questions}

In order to achieve the objective, the study seeks to test the following null hypotheses:

$\mathbf{H}_{01}$ : There is no significant relationship between top management commitment and Total Quality Management implementation in the Nigerian Banking Sector.

$\mathbf{H}_{02}$ : There is no significant correlation between employee involvement and Total Quality Management implementation in the Nigerian Banking Sector.

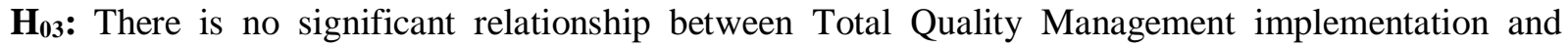
customer satisfaction in the Nigerian Banking Sector.

\section{Literature review}

\section{Conceptual frame work}

\section{The concept of total quality management}

Total Quality Management according to Davies (2003) is a management philosophy that pays attention on people and the work process, with customer satisfaction and improved organizational performance as 
the major concern. It entails the appropriate coordination of work processes that give room for incessant progress in all business divisions with the goal to meet and even beat customer expectations. It stresses totality of quality in all aspects of an organization in order to reduce waste and modify to minimize cost and enhance production efficiency. TQM can be applied to any organization be it small, medium, or large scale, so that they can effective in meeting the demands of their customer, as well as the demands of their shareholders. Most organizations however, are unable to adopt TQM as a result of their failure to comply with its implementation principles and procedures, (Temtime and Solomon, 2002; Mccabe and Hutchinsun, 1994).

The improvement of quality and total quality management most importantly has become very trendy in the developing nations like Nigeria for the past three decades, courtesy of the stern competition in the international market. As the relative economic decline in Nigeria became conspicuous, many industries in Nigeria started to change their conventional business approaches into contemporary approaches aiming at continuous improvement for competitive advantages (Agwu, 2014).

Agus, (1994) argued that if TQM is to be successful, it must be treated as a mind-set to be recognized in an organization's core. This mind-set of quality management and continuous improvement must be treated as a primary objective at all levels in all units of an organization in its expansion and development processes, so as to enable it deal with new challenges in the most appropriate and efficient way. Not only that TQM must be treated as a mind-set of an organization but Curry and Kkolou, (2004) emphasized that the ability of its top management to nurture and champion the implementation of TQM brings about inspiration in the other members of the organization to integrate it into their self-training and daily work, and quality in this manner, finally takes care of itself (Agwu, 2014).

According to the International Standard ISO 8402, the Total Quality Managements of an organization comprised of the Quality Management and Quality Assurance, which centered on quality management through the involvement of all members of the organization, to achieve a long-term success by ensuring customer satisfaction, as well as benefits to all members of the organization and to the larger society (Ljungstrom and Klefsjo, 2002). Total Quality Management according to Kartha (2004) is also a systems approach to management, which is aimed at enhancing value to customers through the design and constant improvement of organizational systems and processes. Though, customers and customer satisfaction is the focal point in TQM, but employee involvement and empowerment are also emphasized. The principles of Total Quality Management as claimed by Ugboro and Obeng (2000 cited in Ogbari and Borishade, 2015), are constant improvement, the commitment of top management to customer satisfaction goal, employee empowerment, as well as customer focus.

Many people though, think that Total Quality Management is old, not knowing that many of the emerging management initiatives are offshoots of Total Quality Management beliefs. Notable among such offshoots are Six Sigma (Klefsjo, Wiklund, and Edgeman, 2001); Lean Sigma; ISO 9000; as well as the Malcolm Baldrige National Quality Award (MBNQA). Irrespective of the several points of view however, the core theme common to all the derivates is the fact that the foundation of TQM is a prevention work process that struggles to improve quality and efficiency, increase productivity, and boost customer satisfaction, (Kartha, 2004; Goldman, 2005). Sashkin and Kiser (1993) suggests the following essential elements for the implementation of a Total Quality Management: (1) use of quality information for improvement, rather than judging or controlling people; (2) authority must imply responsibility; (3) results must be adequately rewarded; (4) the basis of team work must be cooperation and not competition; (5) employees job security must be guaranteed; (6) the working environment must be fair to all; (7) compensation must be reasonable; and (8) employees must be granted ownership stakes.

\section{Top management commitment}

Several researches supported the tact the strong commitment from the top management is a cornerstone in the total quality management philosophy. The result of top management commitment is higher quality performance (Saraph et al., 1989; Flynn et al., 1994; 1995; Ahire et al., 1996; Juran, 1988; Anderson et 
DOI: 10.21522/TIJMG.2015.SE.19.01.Art004

ISSN: $2520-310 \mathrm{X}$

al.,1995). Top management is a catalyst in the TQM implementation, establishing values, goals, and systems to meet and exceed the expectation of customer and leading to improved organizational performance (Ahire et al., 1996; EFQM Award, Wilson and Collier 2000 and KAAPS 2010). Anderson et al. (1994) stated Leadership concept is the ability of top management to create a process, strategic vision for the organization, that is focus on customer requirement. According to Juran \& Gryna (1993), top management are to establish quality policies, establish and deploy quality goals, provide resources, provide problem-oriented training, and improvement. Hence, it is believed that top management commitment is relevant in total quality management. Top management are to accept evaluate, participate in improvement efforts in order to have strategies and goals, alignment of Information System with business strategy that is based on market demand and consumer needs which will lead to organizational performance and profitability. (Saraph et al.,1989; Flynn et al., 1994, 1995; Ahire et al., 1996; Anderson et al., 1995; Black \& Porter, 1996; Crosby, 1979; Deming, 1986; Juran \& Gryna, 1993; Kaynak, 2003; Powell; 1995; Prajogo \& Sohal, 2003; Rao et al., 1999; Sila \& Ebrahimpour, 2005; Wilson \& Collier, 2000). Effective leadership promotes the strategic direction of the company to achieve customer satisfaction and business results.

\section{Strategic planning}

Strategic Quality Planning is a structured process for establishing long-range quality goals, at the highest levels of the organization, and defining the means to be used to reach those goals". Krumwiede \& Charles (2006) emphasized that the strategic aspects of quality are recognized and embraced by top management in the strategic planning process. Strategic Planning allows firms to set clear priorities and allocate resources for the most important things. McKinsey 7s model was developed in 1980s by McKinsey consultants Tom Peters, Robert Waterman and Julian Philips with a help from Richard Pascal and Anthony G. Athos. The model has been widely used by both practitioners and academic as one of the most popular strategic planning tools. The tool is used to analyze the firm's organizational design by looking at 7 key internal elements. These are Strategy, Structure, Systems, shared values, style, staff and skills. The tools will allow organization to identify if all this internal element is effectively aligned and allow organization to achieve their objectives.

The focus of a TQM philosophy includes the vision of the leader in the organization's desired long-term goals and objectives, translating the vision into strategy, goals and policy, strategy development, and strategy into reality (Sila \& Ebrahimpour, 2005). Within the TQM model stipulated by MBNQA, Strategic Planning stresses that long-term organizational sustainability and a competitive environment are key strategic issues that need to be integral parts of an organization's overall planning (NIST, 2010). In the Malcolm Baldrige model, it has been stated that there is a positive link between strategic planning for quality and quality information and analysis (Wilson \& Collier, 2000).

\section{The concept of customer satisfaction}

Customer satisfaction has been defined in several ways, Oliver (1997) defines it as consumer's accomplishment response, it assesses the quality of products or services. In other word, satisfaction evaluates product or service offered to a customer and appraises the level at which the customer's needs and expectations are fulfilled, whether unsatisfactory or satisfactory (Zeithaml and Bitner, 2000). Customer satisfaction measures the gap between customer's expectations and opinion of product or service level of performance (Parasuraman et al., 1988).

They explained further that the term "expectations" implies the benefits a customer feels the product or service should offer and not what it would actually offer. Customer satisfaction could also imply the consumer's forecast about what would probably happen during an impending exchange or transaction. They developed an instrument called SERVQUAL with five components, vis-à-vis assurance, empathy, reliability, responsiveness, and tangibility, to measure the quality of service offered by service organizations. 


\section{Total quality management and customer satisfaction}

Naumann (2010 cited in Ogbari and Borishade, 2015) identified customer satisfaction as an integral part of organisation's strategic planning. It has also been found that total quality management implementation enhances the level of customer satisfaction, which will in turn improve the competitive power of an organisation, and as a result, TQM implementation is sacrosanct to all business organizations (Aghazadeh, 2002).

Customer satisfaction for decades is adjudged to be the pivot of success for every profit-based organization as it influences their customer retention and market share. This is because, a satisfied customer is likely to be less price sensitive, less influenced by competitors, and also stays loyal longer (Dimitriades, 2006). Yang (2006) found that Total Quality Management when combined with human resource management significantly influenced quality performance, particularly relating to employee and customer satisfaction. Agus (2004) also finds that a strong and direct correlation exists between TQM and customer satisfaction. Saravanan and Rao (2006) also found a statistically significant association between the implementation of TQM practices and customer satisfaction and organizational performance. Nadiri and Hussain (2005) also found that service quality facilitates customer satisfaction, kindles repeat purchase, and promotes referrals.

\section{Employee involvement}

For a great number of quality management initiatives, employee involvement is adjudged as an important factor. From the 25 best TQM practices identified, four items are linked closely with employee involvement; they are Human Resource Management, employee empowerment, employee satisfaction and appraisal, as well as rewards and recognition (Sumukadas, 2006). Sumukadas (2006) argued that despite that organizational behavior field has conducted the major part of employee involvement research, several researches are yet to realise the effects of employee involvement on employee performance and employee satisfaction, which at the long run impact on business performance. Plausibly, employee involvement implies that employee who understands a problem is considered as the authorized person to address the problem and as such has the prospect to make the most suitable decisions to get the problem solved (Sun et al, 2000). Employee involvement is also defined as "the extent to which employees producing a product or offering a service has a sense of controlling their work, receiving information about their performance, and being rewarded for the performance of the organization" (Lawler et al., 1992).

\section{Theoretical frame work}

Several frameworks and theories have been adopted for the implementation of Total Quality Management. For the purpose of this study however, the works of Deming (1986) and Juran (Juran \& Gryna, 1993), are reviewed. Deming (1986), who propounded the first TQM concepts created 14 points vis-à-vis provision of constancy purpose for product and service improvement, adoption of quality management as the new working policy, prevention of reliance on mass assessment, putting an end to the emphasis on the cost of production in the production and service system improvement, adopting of new training method, new supervision method, drive out of fear, collaboration between staff areas, eradication of numerical targets for the employee, abolition of numerical quotas, getting rid of the hurdles that thwart the hourly worker, new education and training program, as well as top management commitment to quality managements (Temtime and Solomon 2002). Juran (1986) cited in Tanninena, et al., (2010) further elucidated that the management has the responsibility to establish a quality council, management should also set up the quality policy, the management need to incorporate the time frame for quality goal and finally, management must provide all essential resources needed to accomplish the quality goal.

\section{Methodology}

The descriptive survey research design was adopted for this study. The employees of five selected Money Deposits Banks branches in Akoka Area of Yaba Local Government Area of Lagos State, Nigeria formed 
DOI: 10.21522/TIJMG.2015.SE.19.01.Art004

ISSN: $2520-310 \mathrm{X}$

the population for this study. This comprised of 41 employees of Access Bank Plc. 53 employees of First Bank Nigeria Limited, 45 employees of Guarantee Trust Bank Plc., 36 employees of United Bank for Africa, and 30 employees of WEMA Bank, giving a total of 205 employees. Furthermore, the sample size was statistically determined using the Yaman (1967) formula method as illustrated below;

$$
\begin{aligned}
& n=\frac{N}{1+N e^{2}} \\
& \quad \text { Where } \mathrm{n}=\text { Sample size; } \\
& 1=\text { Constant; } \\
& \quad \mathrm{e}=\text { Error of significance }=0.05 ; \text { and } \\
& \quad \mathrm{N}=\text { Population size } \\
& n=\frac{205}{1+205 *(0.05)^{2}}=\frac{205}{1+205 * 0.0025} \\
& n=\frac{205}{1+0.5125}=\frac{205}{1.5125}=135.5 \cong 136 \therefore n=136
\end{aligned}
$$

Based on the result above, the sample size for this study is 136 respondents. Hence, there is need to ensure that the sample represents each of the five selected banks based to their staff strength. And a result, the Bowley's (1926) stratified proportional allocation formula is adopted. The Bowley (1926) proportional allocation formula is given as:

$n h=\frac{n * N h}{N}$

Where: $\boldsymbol{n} \boldsymbol{h}=$ Number of units allocated to each stratum (bank)

$N=$ Total sample size

$\boldsymbol{N h}=$ Number of employees in each bank

$N=$ Total population

Access Bank Plc.

$n h=\frac{n * N h}{N}=\frac{136 * 41}{205}=27.2 \cong 27$

First Bank Nigeria Limited

$n h=\frac{n * N h}{N}=\frac{136 * 53}{205}=35.2 \cong 35$

Guarantee Trust Bank Plc.

$n h=\frac{n * N h}{N}=\frac{136 * 45}{205}=29.9 \cong 30$

\section{United Bank for Africa}

\section{WEMA Bank}

$$
n h=\frac{n * N h}{N}=\frac{136 * 36}{205}=23.9 \cong 24
$$

$n h=\frac{n * N h}{N}=\frac{136 * 30}{205}=19.9 \cong 20$

Hence, the instrument adopted for this study is a self-structured questionnaire administered to both junior and senior officers of the selected banks, who were randomly selected so as to give each employee of the bank equal chance of being chosen for the study. The questionnaire was designed in four sections (A-D); Section A sought the respondents' demographic data, Section B-D sought their rating of the top management commitment to TQM, employee involvement in TQM implementation, and the level of customer satisfaction respectively. The rating in Sections B-D ranges from 1 to 5, with 1 being the least and 5 the highest rating. The data collected were presented and analysed using frequency distribution tables and charts to present the respondents' demographic data, while Pearson Product Moment Correlation Coefficient is used to test the hypotheses, with the aid of the Statistical Package for Social Scientists (SPSS 21.0), at 0.05 level of significance. 


\section{Results}

Table 1. Percentage distribution of respondents' demographic data

\begin{tabular}{|l|l|l|l|}
\hline Characteristics & Options & Frequency & Percent (\%) \\
\hline \multirow{4}{*}{ Sex } & Male & 61 & 44.9 \\
\cline { 2 - 4 } & Female & 75 & 55.1 \\
\cline { 2 - 4 } & Total & 136 & 100.0 \\
\hline \multirow{4}{*}{ Age } & 25-35 years & 46 & 33.8 \\
\cline { 2 - 4 } & 36-45 years & 53 & 39.0 \\
\cline { 2 - 4 } & Above 45 years & 37 & 27.2 \\
\cline { 2 - 4 } & Total & 136 & 100.0 \\
\hline \multirow{5}{*}{ Experience } & $1-5$ years & 31 & 22.8 \\
\cline { 2 - 4 } & 6-10 years & 61 & 44.9 \\
\cline { 2 - 4 } & $11-15$ years & 24 & 17.6 \\
\cline { 2 - 4 } & 16-20 years & 20 & 14.7 \\
\cline { 2 - 4 } & Total & 136 & 100.0 \\
\hline
\end{tabular}

Source: Field Survey, 2018.

Table 1 above shows that most (75: 55.1\%) of the respondents were female, while the remaining $61(44.9 \%)$ of them were male. Concerning the age group of the respondents, $46(33.8 \%)$ of them were within the age bracket 25-35 years, 53(39.0\%) of them were 36-45 years, and the remaining $37(27.2 \%)$ of them were above 45 years. And finally, the table showed that much (61: 44.9\%) of the respondents had 6-10 years' work experience in the bank, 31(22.8\%) of them had between 1-5 years' work experience, 24(17.6\% had 11-15 years' work experience, while the reaming 20(14.7\%) of the respondents had 16-20 years' work experience in the bank.

\section{Test of hypothesis one}

There is no significant relationship between top management commitment and Total Quality Management implementation in the Nigerian Banking Sector.

Table 2. Correlation statistics

\begin{tabular}{|l|l|l|}
\hline \multicolumn{2}{|c|}{} & top management commitment \\
\hline Total Quality & Pearson Correlation & $.873^{*}$ \\
\cline { 2 - 3 } $\begin{array}{l}\text { Management } \\
\text { implementation }\end{array}$ & Sig. (2-tailed) & .001 \\
\cline { 2 - 3 } & $\mathrm{N}$ & 136 \\
\hline
\end{tabular}

*. Correlation is significant at the 0.1 level (2-tailed).

Table 2 shows $r=.873$, indicating a very strong and direct relationship between management commitment and Total Quality Management implementation, while $p=.001$ indicates a significant relationship between the two variables. Hence, null hypothesis that states "there is no significant relationship between top management commitment and Total Quality Management implementation in the Nigerian Banking Sector" is rejected, while its alternative is accepted.

\section{Test of Hypothesis two}

There is no significant correlation between employee involvement and Total Quality Management implementation in the Nigerian Banking Sector. 
DOI: 10.21522/TIJMG.2015.SE.19.01.Art004

ISSN: $2520-310 \mathrm{X}$

Table 3. Correlation statistics

\begin{tabular}{|l|l|l|}
\hline \multicolumn{2}{|c|}{} & Employee Involvement \\
\hline Total Quality & Pearson Correlation & $.775^{*}$ \\
\cline { 2 - 3 } $\begin{array}{l}\text { Management } \\
\text { implementation }\end{array}$ & Sig. (2-tailed) & .003 \\
\cline { 2 - 3 } & $\mathrm{N}$ & 136 \\
\hline
\end{tabular}

*. Correlation is significant at the 0.1 level (2-tailed).

Table 3 shows $r=.775$, which shows there is a very strong and direct correlation between employee involvement and Total Quality Management implementation, while $p=.003$ depicts a significant correlation between the two variables. The null hypothesis that states "there is no significant correlation between employee involvement and Total Quality Management implementation in the Nigerian Banking Sector" is therefore rejected, and its alternative is accepted.

\section{Test of hypothesis three}

There is no significant relationship between Total Quality Management implementation and customer satisfaction in the Nigerian Banking Sector.

Table 4. Correlation statistics

\begin{tabular}{|l|l|l|}
\hline \multicolumn{2}{|c|}{} & TQM implementation \\
\hline Customer Satisfaction & $\begin{array}{l}\text { Pearson } \\
\text { Correlation }\end{array}$ & $.902^{*}$ \\
\cline { 2 - 3 } & Sig. (2-tailed) & .000 \\
\cline { 2 - 3 } & N & 136 \\
\hline
\end{tabular}

*Correlation is significant at the 0.1 level (2-tailed).

Table 4 shows $r=.902$, which is an indication that a very strong and direct relationship exists between Total Quality Management implementation and customer satisfaction, while $p=.000$ shows that the relationship between the two variables is significant. Therefore, the null hypothesis that states "there is no significant relationship between Total Quality Management implementation and customer satisfaction in the Nigerian Banking Sector" is rejected, while the alternative hypothesis is accepted.

\section{Findings, conclusion and recommendation Discussion of findings}

From the test of the hypothesis one, it was found that there is a very strong, direct and significant relationship between top management commitment and Total Quality Management implementation in the Nigerian Banking Sector. This is in consonance with the principles of TQM propounded by Deming (1986), as top management commitment is the $14^{\text {th }}$ point of Deming for the implementation of Total Quality Management (Temtime and Solomon 2002).

The test of hypothesis two showed that the correlation between employee involvement and Total Quality Management implementation in the Nigerian Banking Sector is very strong, direct, and significant. This is similar to the finding of Sumukadas (2006) that four items from the best 25 TQM practices identified are closely linked with employee involvement, vis-à-vis employee empowerment, Human Resource Management, employee appraisal and satisfaction, as well as recognition and rewards.

The result of the test of hypothesis three indicated that a very strong, direct, and significant relationship exists between Total Quality Management implementation and customer satisfaction in the Nigerian Banking Sector. This is in conformity with the results of Agus (2004) and Saravanan and Rao (2006) that a strong, direct, and statistically significant correlation exists between TQM and customer satisfaction. 
Texila International Journal of Management

Special Edition Apr 2019

\section{Conclusion}

Sequel to the findings of this study, it is concluded that when there is increase in the Nigerian Banking Sector top management commitment to Total Quality Management, there will also be an increase in TQM implementation in the sector. Increase in the involvement of money deposit banks' staff in the TQM implementation process is also tantamount to an increase in the Total Quality Management implementation of the banks. Finally, when the implementation of Total Quality Management is increased in the Nigerian banking sector, there would also be an increase in the level of satisfaction among the banks' customers.

\section{Recommendations}

Following the conclusion above, this study recommends that the top management of the Nigerian banking sector should not only be committed to Total Quality Management, but should also uphold its best practice and be highly committed in doing so. The banks' employees should be made to have a sense of self-actualization and a sense of belonging in the banks with respect to quality management, so as to be more dedicated and collaborate very closely with the management objectives on quality assurance. The employee should also exhibit the best behaviour and manner in relating with the customers, as this will have a direct impact on the customers' impression concerning the quality of service provided. These undoubtedly will affect the employees' satisfaction and enhance their productivity, which at the long run will improve the level of customer satisfaction in the banking sector.

\section{Reference}

[1].Aghazadeh, S. (2002), "Implementation of total quality management in the managed care industry", The Total Quality Management Magazine, 14(2), 79-91.

[2].Agus, A. (2004), "Total Quality Managements a focus for improving overall service performance and customer satisfaction: an empirical study on a public service sector in Malaysia", Total Quality Management and Business Excellence, 15(5), 615-28

[3].Agwu, E. M. (2014). An investigative analysis of factors influencing E-business adoption and maintenance of commercial websites in Nigeria; Basic Research Journal of Business Management and Accounts. 3(1), 05-16. Accessed October 2018 - Available online at: http//www.basicresearchjournals.org

[4].Ahire, S., Golhar, D., \& Waller, M. (1996). Development and Validation of TQM Implementation Constructs. Decision Sciences, 27(1), 23-56. http://dx.doi.org/10.1111/j.1540-5915.1996.tb00842.x

[5].Anderson, J.C., Rungtusanatham, M., \& Schroeder, R.G. (1994). A Theory of Quality Management Underlying the Deming Management Method. Academy of Management Review, 19(3), 472-509.

[6].Anderson, J.C., Rungtusanatham, M., Schroeder, R.G., \& Devaraj, S. (1995). A Path Analytic Model of a Theory of Quality Management Underlying the Deming Management Method: Preliminary Empirical Findings. Decisions Sciences, 26(5), 637-658. http://dx.doi.org/10.1111/j.1540-5915.1995.tb01444.x

[7].Anderson, J.C., Rungtusanatham, M., Schroeder, R.G., \& Devaraj, S. (1995). A Path Analytic Model of a Theory of Quality Management Underlying the Deming Management Method: Preliminary Empirical Findings. Decisions Sciences, 26(5), 637-658. http://dx.doi.org/10.1111/j.1540-5915.1995.tb01444.x

[8].Black, S.A., \& Porter, L.J. (1996). Identification of the Critical Factors of TQM. Decision Sciences, 27(1), 1-21. http://dx.doi.org/10.1111/j.1540-5915.1996.tb00841.x

[9].Bowley, A. L. (1926). Measurements of precision attained in sampling. Bulleting of the International Statistics Institute, Amsterdam, 22(1), 1-62.

[10]. Crosby, P. (1979). Quality Is Free. New York, And Mentor

[11]. Curry, A., \& Kkolou, E. (2004). Evaluating CRM to contribute to Total Quality Management improvement: A cross-case comparison. The Total Quality Management Magazine, 16, 314-324.

[12]. Davies, E.C. (2003). Quality: Its historical context. Engineering Management, 13(2), 14-17.

[13]. Deming, W. E. (1986), Out of the Crisis, MIT Press, Cambridge, MA

[14]. Dimitriades, A. S. (2006). Customer satisfaction, loyalty and commitment in service organizations: some evidence from Greece. Management Research News, 29(12), 782-800. 
DOI: 10.21522/TIJMG.2015.SE.19.01.Art004

ISSN: $2520-310 \mathrm{X}$

[15]. EFQM. (2010). European Foundation Quality Model (EFQM 2010). [Online] Available: http://www.efqm.org . [16]. Flynn, B.B., Schroeder, R.G., \& Sakakibara, S. (1994). A Framework for Quality Management Research and an Associated Measurement Instrument. Journal of Operations Management, 11(4), 339-366. http://dx.doi.org/10.1016/S0272-6963(97)90004-8

[17]. Flynn, B.B., Schroeder, R.G., \& Sakakibara, S. (1995). The Impact of Quality Management Practices on Performance and Competitive Advantage. Decision Sciences, 26(5), 659-691. http://dx.doi.org/10.1111/j.15405915.1995.tb01445.x

[18]. Goldman, H.H. (2005), "The origins and development of quality initiative in American business", The Total Quality Management Magazine, 17(3), 217-25.

[19]. Juran, \& F. M., Gryna. (1993). Quality Planning and Analysis (3rd ed.). McGraw-Hill Book Company: New York. J

[20]. Juran, J.M. (1988). On planning For Quality. London: Collier Macmillan.

[21]. KAAPS. (2010). King Abdullah II Award for Excellence in the private sector (KAAPS Booklet 2010). [Online] Available: http://www.kaaps.jo/award-criteria (August 25, 2011)

[22]. Kartha, C. P. (2004). A comparison of ISO 9000: 2000 quality system standards, QS9000, ISO/TS 16949 and Baldrige criteria. Total Quality Management Magazine, 16, 331-340.

[23]. Kaynak, H. (2003). The Relationship between Total Quality Management Practices and Their Effects on Firm Performance. Journal of Operations Management, 21(4), 405-435. http://dx.doi.org/10.1016/S0272-6963(03)000044

[24]. Kenya Institute of Management (2009). Total Quality Management: Theory, Concepts and Practice. Macmillan Publishers, Kenya.

[25]. Klefsjo, B., Wiklund, H., \& Edgeman, R. L. (2001). Six sigmas seen as methodology for total quality management. Measuring Business Excellence, 5(1), 31-36.

[26]. Krumwiede, K. R., \& Charles, S. L. (2006). Finding the Right Mix. How to Match Strategy and Management Practices to Enhance Firm Performance. Strategic Finance, 87, 37-43.

[27]. Lawler, E. E. III, Mohrman, S. A. and Ledford, G. E. Jr. (1992), Employee Involvement and Total Quality Management: Practices and Results in Fortune 1000 Companies, Jossey-Bass, San Francisco, CA

[28]. Ljungstrom, M., \& Klefsjo, B. (2002). Implementation obstacles for a work development-oriented Total Quality Management strategy. Total Quality Management, 13, 621-634.

[29]. Mccabe, D. \& Hutchinsun, I. (1994) Quality Initiatives in the Financial Services, Manchester, UK: Manchester School of Management, UMIST

[30]. Muma, B. O., Mironga, J.M., and Oruma, B. W. (2014). Top management commitment towards implementation of total quality management (tqm) in construction companies in Nakuru County-Kenya. International Journal of Economics, Finance and Management Sciences, 2(6): 332-338

[31]. Nadiri, H., \& Hussain, K. (2005). Diagnosing the zone of tolerance for hotel services. Managing Service Quality, 15(3), 259-77

[32]. NIST. (2010). National Institute of Standards and Technology: the 2009-2010 Criteria for Performance Excellence (MBNQA). [Online] Available: http://www.nist.gov/baldrige/publications/criteria.cfm.

[33]. Odiaka, B. (1991). Nigerian workers attitude to work. Management in Nigeria, March - April, Vol.27(2).

[34]. Ogbari, M. and Borishade, T. T. (2015). Strategic imperatives of total quality management and customer satisfaction in organizational sustainability. International Journal of Academic Research in Business and Social Sciences, 5(4), 1-22

[35]. Oliver, R.L. (1997), Satisfaction: A Behavioral Perspective on the Consumer, McGraw-Hill, New York, NY.

[36]. Parasuraman, A., Zeithaml, V.A. and Berry, L.L. (1988), "SERVQUAL: a multiple item scale for measuring consumer perceptions of service quality", Journal of Retailing, 64,12-40.

[37]. Powell, T.C. (1995). Total Quality Management as Competitive Advantage: A Review and Empirical Study. Strategic Management Journal, 16, 15-37. http://dx.doi.org/10.1002/smj.4250160105 
Texila International Journal of Management

Special Edition Apr 2019

[38]. Prajogo, D., Sohal, S. (2003). The Relationship between TQM Practices, Quality Performance, and Innovation Performance: an Empirical Examination. International Journal of Quality and Reliability Management, 20(8), 901918. http://dx.doi.org/10.1108/02656710310493625

[39]. Rao, S. S., L. E. Solis, \& Raghu-Nathan. (1999). A Framework for International Quality Management Research: Development and Validation of a Measurement. Total Quality Management, 10(7), 1047-1075. http://dx.doi.org/10.1080/0954412997226

[40]. Saraph, J.V., Benson, P.G., \& Schroeder, R.G. (1989). An Instrument for Measuring the Critical Factors of Quality Management. Decision Sciences, 20, 810-829. http://dx.doi.org/10.1111/j.1540-5915.1989.tb01421.x

[41]. Saravanan, R., \& Rao, K. S. P., (2006). An Analysis of Total Quality Service Dimensions in Service Sector-A case study. International Journal of Management and Systems, 22(8), 261-267.

[42]. Sashkin, M., \& Kiser, K. (1993). Putting total quality management to work. San Francisco: Berrett-Koehler [43]. Sila, I. (2007). Examining the Effects of Contextual Factors on TQM and Performance through the Lens of Organizational Theories: An Empirical Study. Journal of Operations Management, 25, 83-109. http://dx.doi.org/10.1016/j.jom.2006.02.003

[44]. Sila, I., \& Ebrahimpour, M. (2005). Critical Linkages among TQM Factors and Business Results. International Journal of Operations and Production Management, 25(11), 1123-55.http://dx.doi.org/10.1108/01443570510626925 [45]. Sumukadas, N. (2006). Employee involvement: A hierarchical conceptualisation of its effect on quality. The International Journal of Quality \& Reliability Management, 23(2), 143- 161.

[46]. Sun, H., Ip, K. H., Agnes Y.K. Tam, \& Frick, J. (2000). Employee involvement and quality management. The TQM Magazine, 12(5), 350- 354

[47]. Tanninena, K., Puumalainen, K. \& Sandstrom, J. (2010). The power of Total Quality Management: analysis of its effects on profitability, productivity and customer satisfaction. Total Quality Management, 21(2), 171-184.

[48]. Temtime, Z., \& Solomon, G. H. (2002). Total quality management and the planning behavior of SMEs in developing economies. Total Quality Management Magazine, 14, 181-191.

[49]. Wilson, D. D., \& Collier, D. A. (2000). An Empirical Investigation of the Malcolm Baldrige National Quality Award Causal Model. Decision Science, 31(2), 361- 390. http://dx.doi.org/10.1111/j.1540-5915.2000.tb01627.x

[50]. Yamane, T. (1967). Statistics: An introductory analysis. New York: Harper and Row.

[51]. Yang, C. C. (2006). The impact of human resource management practices on the implementation of total quality management. The Total Quality Management Magazine, 18, 162-173

[52]. Zeithaml, V.A. and Bitner, M.J. (2000), Services marketing, McGraw-Hill, New York, NY 